\title{
Adsorption of Streptococcus mutans on Chemically Treated Hydroxyapatite
}

\author{
W. J. O'Brien, P. L. Fan, W. J. Loesche, M. C. Walker, IV, and A. Apostolids \\ The University of Michigan, School of Dentistry, Ann Arbor, Michigan 48109, USA
}

Adsorption of Streptococcus mutans on hydroxyapatite and chemically treated hydroxyapatite was studied. Zeta potentials of the surfaces were measured. Chemically treated hydroxyapatite gave higher $\zeta$ potentials and lower $\mathrm{S}$ mutans adsorption.

\section{J Dent Res 57(9-10):910-914, Sept.-Oct. 1978}

The adsorption of oral bacteria and especially Streptococcus mutans on enamel is considered an important factor in the formation of caries. Synthetic hydroxyapatite surfaces have been used for simulation studies by several investigators. Of special interest is the adsorption of proteins, dextrans and $S$ mutans on hydroxyapatite. ${ }^{1-5}$ The adsorption of $S$ miteor onto hydroxyapatite has been reported in terms of adsorption sites and affinity constants. ${ }^{6}$ Studies on competitive binding of streptococci to surfaces have also been reported. ${ }^{7}$ Treating the surface by other components influences the adsorption of dextran and $S$ mutans. Dextran adsorption was decreased when the hydroxyapatite was precoated with protein. ${ }^{8}$ Adsorption of $S$ mutans decreased on hydroxyapatite surfaces treated with protein or fluoride. ${ }^{9,10} \mathrm{In}$ the past, the use of chemicals on enamel surfaces to prevent or retard caries formation has been based mainly on an increase in resistance to acid dissolution. ${ }^{11-12}$ This study is to investigate the adsorption of $S$ mutans on chemically treated hydroxyapatite with respect to surface properties.

Received for publication December 9, 1977.

Accepted for publication February 23, 1978.

This research was supported in part by Research Grant DE-03480 from the National Institutes of Health, National Institute of Dental Research, Bethesda, Maryland 20014.

* Medium 199 E-11, Grand Island Biological Co., Grand Island, NY.

$\dagger$ Spectronic 20, Bausch and Lomb, Rochester, NY.

$\dagger$ Coulter Counter, Coulter Electronics, Inc., Hialeah, $\mathbf{F 1}$

Hio Gel HTP, Bio-Rad Laboratories, Richmond, Ca.

§ Imperial Chemical Industries, Holland.

I Pharmcia Fine Chemicals AB, Uppsala, Sweden.

\section{Materials and Methods}

Streptococcus mutans (M4S), a recent human isolate (serotype c), was grown anaerobically in a chemically defined medium* for 24 hours. The bacteria were harvested by centrifugation, washed twice, and redispersed by sonification in double filtered distilled water to a concentration of $2.42 \times 10^{9}$ microorganisms/ ml. The purity of the bacteria was monitored by streaking aliquots on agar medium. For use in adsorption experiments, the bacteria were kept at $37 \mathrm{C}$ and were in stationary phase. They were used within 3 hours of harvest.

Concentrations of bacterial suspensions were measured by an optical density method at 550 $\mathrm{nm}$ using a spectrophotometer. $\dagger$ A standard curve for cell number was calibrated against a particle counter $\uparrow$ The amount of bacteria adsorbed in each experiment was indicated by the difference in concentrations of the bacterial suspensions before and after adsorption.

Hydroxyapatite powder used for the experiments was chromatographic grade. $\$$ Solutions used for chemical treatment were $0.2 \%$ chlorhexidine gluconate $\$$ and $2 \%$ Dextran $\|$ (molecular weight 40,000 ). Distilled water was used as control.

Chemical treatment was by adding $5 \mathrm{ml}$ of the treatment solution to $15 \mathrm{mg}$ of hydroxyapatite powder in a vial. The mixture was shaken for 5 minutes and then allowed to settle for 5 minutes; $4.5 \mathrm{ml}$ of the supernatant liquid was withdrawn. The treated hydroxyapatite was washed by adding $5 \mathrm{ml}$ of distilled water and the shaking and settling repeated, after which $5 \mathrm{ml}$ of the liquid was withdrawn. A final washing with $10 \mathrm{ml}$ of distilled water was applied. After withdrawing $10 \mathrm{ml}$ of the wash, $0.5 \mathrm{ml}$ of liquid was left in the vial with the hydroxyapatite.

For adsorption experiments, $5 \mathrm{ml}$ of the bacterial suspension was added to each vial of chemically treated hydroxyapatite. Control experiments were performed on hydroxyapatite treated with distilled water and on chemical solutions without hydroxyapatite. The vials 
were immersed in a $37 \mathrm{C}$ constant temperature water bath and shaken for 30 minutes. The contents were then left to settle. After $5 \mathrm{~min}$ utes, $3.5 \mathrm{ml}$ of the suspension were withdrawn. Optical densities of the suspensions were measured after addition of 2 drops of $2.5 \mathrm{~N} \mathrm{HCl}$ to dissolve any suspended hydroxyapatite particles. The effect of HCl on optical densities of suspensions was incorporated in the calibration. Sixteen measurements were made for each chemical treatment experiment.

Adsorption kinetics of $S$ mutans on chemically treated hydroxyapatite was measured in a similar method with adsorption times of 2,5 , and 30 minutes at $37 \mathrm{C}$. The adsorption isotherm of $S$ mutans on untreated hydroxyapatite was measured at the same temperature using bacterial suspensions with concentrations from $6 \times 10^{8} / \mathrm{ml}$ to $4.4 \times 10^{9} / \mathrm{ml}$. Adsorption time was 30 minutes.

Surface potentials ( $\zeta$ potentials) of the chemically treated hydroxyapatite powders and of the bacteria suspension in distilled water were obtained from electrophoretic mobility measurements by means of a Zeta-Meter. ${ }^{*}$ The $\zeta$ potentials were calculated from the Helmholtz-Smoluchowski equation: ${ }^{18}$

$$
\varphi=\frac{u 4 \pi \eta}{\varepsilon}
$$

where $u$ is the electrophoretic mobility or velocity at un't potential gradient, $\eta$ the viscosity of the liquid, and $\varepsilon$ the dielectric constant of the liquid. Ten zeta potential measurements were made for the bacteria suspension and for

* Zeta-Meter Inc., New York, NY.
† International Scientific Instruments, Inc., Moun-
tain View, Ca.

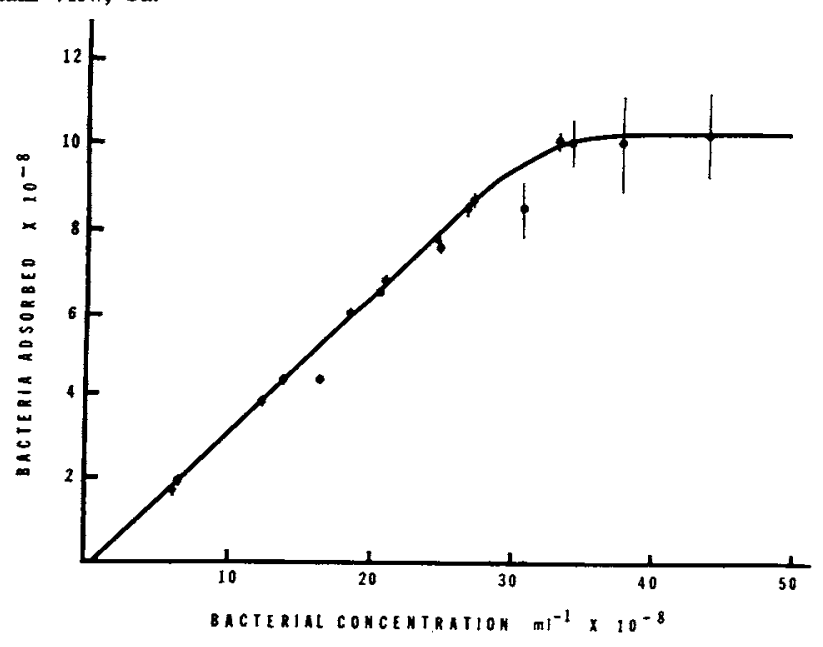

TABLE

$\zeta$ Potential and Amount of $S$ mutans AdSorbed on Ghemically Treated HYDROXYAPATITE

\begin{tabular}{lcc}
\hline \hline Treatment & $\begin{array}{c}s \text { mutans } \\
\text { Adsorbed per mg } \\
\text { Hydroxyapatite } \\
\left(\times 10^{-8}\right)\end{array}$ & $\begin{array}{c}\zeta \text { Potential } \\
(\mathrm{mV})\end{array}$ \\
\hline $\begin{array}{c}\text { Chlorhexidine } \\
\text { Gluconate, } 0.2 \%\end{array}$ & $2.90(1.19)$ & $-13.4(.9)$ \\
$\begin{array}{c}\text { Dextran (MW } \\
\quad 40,000), 2 \%\end{array}$ & $3.56(0.45)$ & $\ldots 9.9(.8)$ \\
$\begin{array}{c}\text { Distilled Water } \\
(\text { control) }\end{array}$ & $4.35(0.88)$ & $-9.0(.8)$ \\
\hline
\end{tabular}

Standard deviations in parentheses.

each chemical treatment experiment.

Surface morphologies of the treated hydroxyapatite powders were studied by scanning electron microscopy. The powders were dried, coated with gold by vapor deposition, and examined in a scanning electron microscope. $f$

\section{Results}

Adsorption isotherm at $37 \mathrm{C}$ for $S$ mutans on hydroxyapatite is shown in Figure 1. The amount of bacteria adsorbed per mg of hydroxyapatite increased linearly with bacterial concentration up to about $2.7 \times 10^{9} / \mathrm{ml}$, eventually leveling off to a plateau at $1.4 \times 10^{9} \mathrm{bac}-$ teria adsorbed by one $\mathrm{mg}$ of hydroxyapatite. For kinetics of bacterial adsorption on chemically treated hydroxyapatite see Figure 2.

Amounts of $S$ mutans adsorbed on chemically treated hydroxyapatite after 30 minutes are shown in the Table. Statistical evaluation of the results using the Krusakal-Wallis test and
Fig 1. - Adsorption isotherm of $S$ mutans on hydroxyapatite showing bacteria adsorbed $/ \mathrm{mg}$ hydroxyapatite versus bacterial concentration. 


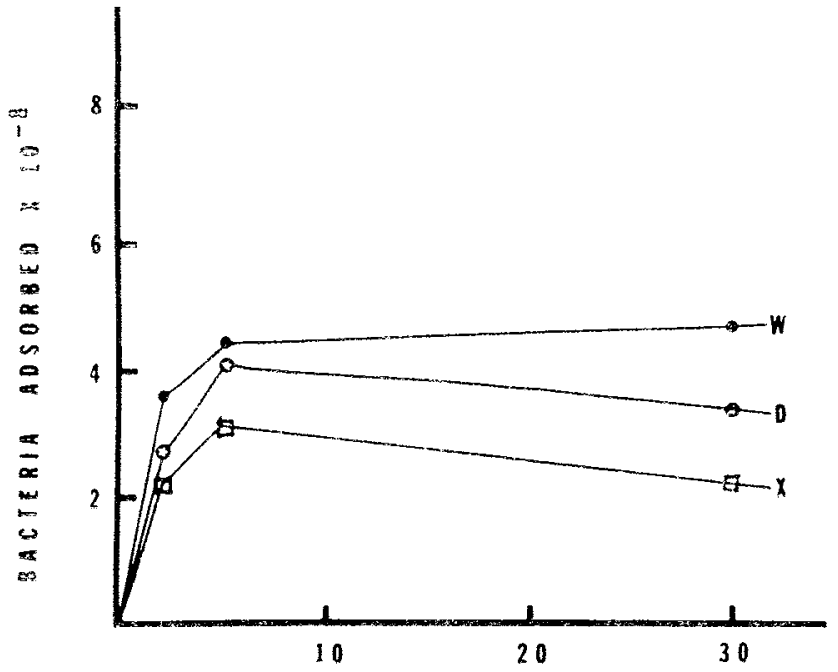

FIG 2.-Adsorption kinetics of $S$ mutans on chemically treated hydroxyapatite, showing bacteria adsorbed/mg hydroxyapatite versus time. Chlorhexidine (X), dextran (D), water (W).

\section{IIME MINUTES}

Wilson-Mann-Whitney statistic for multiple comparisons showed that at $\alpha=0.005$ the adsorption values of hydroxyapatite treated with chlorhexidine gluconate or with dextran were significantly different from the adsorption value on hydroxyapatite treated with distilled water.

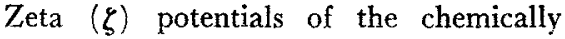
treated hydroxyapatite powders are also shown in the Table. Statistical evaluation of the results using the Student-Newman-Keuls test showed the $\zeta$ potentials are significantly different at $\alpha=0.05$. The $\zeta$ potential of $S$ mutans in distilled water was $-13.7 \mathrm{mV}$ with a standard deviation of $1.2 \mathrm{mV}$.

Scanning electron microscopy revealed no detectable change in the surface morphology of the hydroxyapatite powders after chemical treatments when compared with the control experiment using distilled water.

The chemical solutions used did not affect the optical densities of the bacterial suspensions except for dilution effects. No agglutination of bacteria was observed.

\section{Discussion}

The adsorption isotherm of $S$ mutans on hydroxyapatite (Fig 1) showed that adsorption varied linearly with bacterial concentration and then leveled off to a plateau. The linear part of the adsorption isotherm indicated that bacterial concentration was limiting adsorption. The plateau portion of the adsorption isotherm corresponded to an adsorption site limiting adsorption. The number of $S$ mutans adsorbed by
$1 \mathrm{mg}$ of hydroxyapatite was $1 \times 10^{\circ}$. As $S$ mutans cells are about $1 \mu \mathrm{m}$ in diameter and the hydroxyapatite powder has a surface area of $7.24 \mu \mathrm{m}^{2} / \mathrm{mg},{ }^{19}$ the maximum adsorption corresponds to 0.014 monolayer of bacteria. This assumes that $S$ mutans occupies $1 \mu \mathrm{m}^{2}$ of space and that there exists no interaction among the adsorbed $S$ mutans and the $S m u$ tans in suspension. However, it was unlikely that a simple adsorption mode was followed. The adsorption characteristics were probably complex involving inhomogeneity of sites, bacterial interactions, and electrostatic and surface interactions.

Results of adsorption kinetics of $S$ mutans on chemically treated hydroxyapatite (Fig 2) indicated that in all cases there was rapid adsorption in the first 5 minutes followed by a slow leveling off to essentially a steady value at 30 minutes. Similar adsorption kinetics have been reported by $\mathrm{McGaughy}$ et al for proteins and for $S$ mutans on hydroxyapatite. $3,4,9$

Zeta potential measurements showed that chemical treatments of hydroxyapatite resulted in different surface potentials (Table). Zeta potential is an important factor in determining the stability of colloids and in adsorption and adhesion processes. For a bacteria to be adsorbed onto a surface, the two bodies have to be sufficiently close for physical forces of adhesion (e.g. Van der Waal's forces) and chemical interaction (chemisorption) to occur. ${ }^{20-24}$ Kinetic forces bring the bacteria close to the surface but are opposed by electrostatic repulsion if the surfaces are both negative or both 
positive. Experimental results showed that the $S$ mutans was negatively charged $(-13.7 \mathrm{mV})$ and the chemically treated hydroxyapatite surfaces were also negatively charged. Thus, a higher negative $\zeta$ potential surface would be less favorable toward close approach because of higher electrostatic repulsion and consequently, a low probability of bacteria adsorption onto the surface. This is in agreement with the $S$ mutans adsorption values obtained. Chlorhexidine treated hydroxyapatite, with a $\zeta$ potential of $-13.4 \mathrm{mV}$, decreased thr hacterial adsorption by $33 \%$ and dextran treated hydroxyapatite $(\zeta$ potential $-9.9 \mathrm{mV})$ decreased the adsorption by $18 \%$ when compared with distilled water treated hydroxyapatite $(-9.0 \mathrm{mV})$ used as a control. The effect of $\zeta$ potential on adsorption was clearly demonstrated-the higher the $\zeta$ potential of the surface, the less the amount of $S$ mutan adsorbed. Olsson, Glantz and Krasse reported on the effect of $\zeta$ potentials on the adhesion of $S$ salivarius, $S$ sanguis, and $S$ mutans onto dentin by a washing technique. $S$ mutans with different $\xi$ potentials were found to adhere differently. ${ }^{25}$ Various species of streptococci with similar $\zeta$ potential also gave different results. Gallium ions and aluminum ions gave increased adhesion and the effect was attributed to a reduced repulsive force in the presence of counter ions. Zeta potentials and electrostatics are important factors in initial adsorption of bacteria on surfaces. In long-term adsorption and adhesion of bacteria, other factors, such as physical and chemical interactions between cells and surfaces, have to be taken into consideration.

Scanning electron microscopy results showed that there was no detectable change in surface morphology of the hydroxyapatite powders after chemical treatment. The differing amounts of $S$ mutans adsorbed onto these surfaces, therefore, were not the results of artifacts of chemical treatment.

Treatments of hydroxyapatite by chlorhexidine gluconate and by dextran decreased the amount of $S$ mutans adsorbed onto these surfaces. A decrease in $S$ mutans adsorption in this experiment parallels the decrease in plaque index scores resulting from topical applications and oral rinses of chlorhexidine reported by Löe and Schiott. ${ }^{26}$ Schiott et al showed that this decrease did not result from the bactericidal property of chlorhexidine. ${ }^{27}$ Adsorption of chlorhexidine onto hydroxyapatite has been shown to have a maximum uptake of $18 \mu$ moles/gm hydroxyapatite. ${ }^{28}$ This uptake of chlohexidine would alter the surface properties, including $\zeta$ potential, of the hydroxyapatite resulting in a decrease in bacterial adsorption as well as long-term adhesion. A similar explanation can be applied to the observed decrease in $S$ mutans adsorption on dextran treated hydroxyapatite. Although agglutination and adhesion of bacteria have been attributed to the presence of dextrans, such dextrans are insoluble, high molecular weight $(\mathrm{MW}=2,000,000)$ or are produced by the bacteria.29,30 Lower molecular weight $(\mathrm{MW}=20,000)$ dextrans have been shown to retard the formation of dental plaque by inhibiting the synthesis of insoluble dextrans by the bacteria. ${ }^{31,32}$ In the present experiment, the dextran used had a molecular weight of 40,000 and was water soluble. No agglutination of $S$ mutans was observed in the presence of this dextran. The decrease in $S$ mutans adsorption on dextran treated hydroxyapatite agrees with results of Gibbons. ${ }^{30}$

\section{Conclusions}

Adsorption of $S$ mutans on hydroxyapatite and dextran or chlorhexidine treated hydroxyapatite was studied. Zeta potentials of the chemicaliy treated surfaces were obtained by electrophoretic mobility measurements. Surface morphologies were studied by scanning electron microscopy. Hydroxyapatite treated with chlorhexidine gluconate and with low molecular weight dextran gave higher $\zeta$ potentials and lower $S$ mutans adsorption compared with untreated hydroxyapatite. The decrease in adsorption was attributed to changes in surface potentials and chemical properties of the chemically treated hydroxyapatite surfaces.

\section{References}

i. HAY, D.I.: The Adsorption of Salivary Proteins by Hydroxyapatite and Enamel, Arch Oral Biol 12:937-946, 1967.

2. Hillman, J.D.; Van Houte, J.; and GibBONS, R.J.: Sorption of Bacteria to Human Enamel Powder, Arch Oral Biol 15:899 $903,1970$.

3. MaGavghery, $\mathrm{C}_{\text {., }}$ and Stoweld, E.C.: Adsorption of Salivary Protein by Hydroxyapatite: Relations Between the Effects of Galcium Ions, Hydrogen Ions, Temperature and Exposure Time, I Dent Res 50:541$550,1971$.

4. McGaughery, C., and Stowell, E.C.: Adsorption of Salivary Proteins by Hydroxyapatite: Effect of Phosphate Ions and Interdependence of the Effects of Phosphate and 
Hydrogen Ions, $J$ Dent Res 53:121-126, 1974.

5. Pearce, E.I.F., and Bibby, B.G.: Effects of Time, Surface Area, $\mathrm{pH}$ and Some Ions on Protein Adsorption by Bovine Enamel, Arch Oral Biol 11:825-832, 1966.

6. Gibbons, R.J.; Moreno, E.C.; and SpinELL, D.M.: Model Delineating the Effects of a Salivary Pellicle on the Adsorption of Streptococcus miteor onto Hydroxyapatite, Infect Immun 14:1109-1112, 1976.

7. Liljemark, W.F., and SGhaur, S.V.: Competitive Binding Among Oral Streptococci to Hydroxyapatite, $J$ Dent Res 56:157-165, 1977.

8. Rolla, G.: Adsorption of Dextran to SalivaTreated Hydroxyapatite, Arch Oral Biol 16: $527-533,1971$.

9. MaGaughery, C. ; Field, B.D.; and StowELL, E.C.: Effect of Salivary Proteins on the Adsorption of Cariogenic Streptococci by Hydroxyapatite, J Dent Res 50:917-922, 1971.

10. Rolia, G., and Melsen, B.: Desorption of Protein and Bacteria from Hydroxyapatite by Fluoride and Monofluorophosphate, Caries Res 9:66-73, 1975.

11. Ericson, T., and Ericson, Y.: Effect of Partial Fluorine Substitution on the Phosphate Exchange and Protein Adsorption of Hydroxyapatite, Helv Odont Acta 11:1014, 1967.

12. Roseman, T.J.; Higughi, W.I.; Hodes, B.; and HeFferren, J.J.: The Retardation of Enamel Dissolution Rates by Adsorbed Long-Chain Ammonium Chlorides, J Dent Res 48:509-520, 1969.

13. Green, R.W., and Walsh, J.P.: The Protection of the Wet Enamel Surface by Adsorbed Films, J Dent Res 30:218-224, 1951.

14. Irwin, M.; Leaver, A.G.; and WaLsh, J.P.: Further Studies on the Influence of Surface Active Agents on Decalcification of the Enamel Surface, J Dent Res 36:166$172,1957$.

15. Leaver, A.G.: Long Chain Aliphatic Amines as Potential Caries-Preventing Agents, New Zealand Dent J 67:99-106, 1971.

16. MAgrill, D.S.: The Reduction of the Solubility of Hydroxyapatite in Acid by Adsorption of Phytate from Solution, Arch Oral Biol 18:591-600, 1973.

17. MuhlemanN, HR., and Schait-BonisSONE, A.: Solution Rate in Acid Buffer of Intact and White Enamel Treated by Various Phosphates and Fluorophosphates, Helv Odont Acta 5: 14-15, 1961.

18. Adamson, A.W.: Physical Chemistry of Surfaces, 2nd Edition, New York: Interscience, 1967.
19. Rootare, H.M.: Free Surface Energies, Heats of Solution and Heats of Immersion of Calcium Apatite Powders. Ph.D. Thesis, The University of Michigan, 1973.

20. Marshall, K.C.; Stout, R.; and MitCHELL, R.: Mechanism of the Initial Events in the Sorption of Marine Bacteria to Surfaces, J Gen Microbiol 68:337-348, 1971

21. Parsegran, V.A., and Gingell, D.: A Physical Force Model of Biological Membrane Interaction, in Recent Advances in Adhesion, LeE, L.H. (ed), New York: Gordon and Breach, 1973, pp 153-191.

22. Parsegian, V.A., and Gingell, D.: On the Electrostatic Interaction Across a Salt Solution Between Two Bodies Bearing Unequal Charges, Biophys J 12:1192-1204, 1972.

23. NinhaM, B.W., and PARsegian, V.A.: Van der Waals Forces, Special Characteristics in Lipid-Water Systems and a General Method of Calculation Based on the Lizshitz Theory, Biophys J 10:646-663, 1970.

24. Parsegian, V.A., and Ninham, B.W.: Temperature-Dependent Van der Waals Forces, Biophys J 10:664-674, 1970.

25. Olsson, J.; Glantz, P.; and Krasse, B.: Surface Potential and Adherence of Oral Streptococci to Solid Surfaces, Scan J Dent Res 84:240-242, 1976.

26. Löв, H., and Schiotr, C.R.: The Effect of Mouthrinses and Topical Application of Chlorhexidine on the Development of Dental Plaque and Gingivitis in Man, $J$ Periodont Res 5:79-83, 1970.

27. Schiott, C.R.; Löe, H.; Jensen, S.B.; Kilian, M.; Davis, R.M.; and Glavind, K.: The Effect of Chlorhexidine Mouthrinses on the Human Oral Flora, $J$ Periodont Res 5 : 84-89, 1970.

28. Rölla, G.; LöE, M.; and SGHiotT, C.R.: The Affinity of Chlorhexidine for Hydroxyapatite and Salivary Mucins, $J$ Periodont Res 5:90-95, 1970.

29. Gjermo, P., BaAstad, K.L.; and Rölla, G.: The Plaque Inhibiting Capacity of 11 Antibacterial Compounds, 7 Periodont Res 5: 102-109, 1970.

30. Gibbons, R.J., and Fitzgerald, R.J.: Dextran Induced Agglutination of Streptococcus mutans and Its Potential Role in the Formation of Microbial Dental Plaque, $J$ Bacteriol 98:341-346, 1969.

31. Gibbons, R.J., and Keyes, P.H.: Inhibition of Insoluble Dextran Synthesis, Plaque Formation and Dental Caries in Hamsters by Low Molecular Weight Dextran, Arch Oral Biol 14: 721-724, 1969.

32. Gibbons, R.J., and Van Hovte, J.: On the Formation of Dental Plaque, $J$ Periodont $44: 347-360,1973$. 